\title{
Influence of indoor conditions on microbial diversity and quantity in schools
}

\author{
Dahae Seong ${ }^{1}$, R. Sean Norman ${ }^{2}$, and Shamia Hoque ${ }^{1, *}$ \\ ${ }^{1}$ University of South Carolina, Department of Civil and Environmental Engineering, 300 Main st., Columbia, SC, USA \\ ${ }^{2}$ University of South Carolina, Department of Environmental Health Science, Arnold School of Public Health, 800 Sumter st., \\ Columbia, SC, USA
}

\begin{abstract}
HVAC systems consumes $37 \%$ of the electricity in educational buildings. Energy consumption varies depending on the ventilation strategy. School buildings have a responsibility of ensuring energy performance and maintenance of indoor environmental quality for its occupants. This study assesses the efficiency of the ventilation system in terms of the microbes present in the spaces. Microorganisms and particulate matters were sampled in classrooms, locker rooms, libraries in two high schools and an elementary school. Six bacterial species and seven fungal species were identified. The most abundant microorganisms were Staphylococcus sp., Bacillus sp., and Micrococcus sp. Elementary school, especially kindergarten, showed higher microbial concentration and particulate matter as a result of higher human activity. Microbial concentration was influenced by the types of room in the same building with the same ventilation system. Canonical correspondence plot (CCA) determined that gender and school type have significant effects. The presence of Bacillus sp., Aerococcus sp., Corynebacterium sp., and Penicillium sp. was significantly related to gender, while Staphylococcus sp. and Alternaria sp. were related to type of school. The presence of Aerococcus sp. and Micrococcus sp. depended on the distance from the vent location. Relatively lower number of Aerococcus sp. was detected when the distance between sampling site and vent was less than $2 \mathrm{~m}$. Micrococcus $\mathrm{sp}$. was generally detected when the distance was $<3.5 \mathrm{~m}$. The distance from the door was not significant.
\end{abstract}

\section{Introduction}

Poor air quality causes health problem $[1,2]$, discomfort $[3,4]$, and deterioration of learning performance [5]. More and more buildings are being designed as air-tight structures to save energy, however, this could lead to degradation of indoor air quality through containment of contaminated air in dead zones in the room, or introduce outdoor pollutants indoors depending on the ventilation condition $[6,7]$. Even though ventilation systems have evolved over decades, poor air quality persists. Therefore, appropriate ventilation strategy is required to maintain air quality and prevent waste of energy.

According to the data from EIA (Energy Information Administration, US), HVAC systems consume most of the electricity following lighting, refrigeration, and computing in educational buildings in USA [8]. Schools spend approximately $\$ 130$ per student for electricity [8]. School's median energy costs based on EPA data are $\$ 1.30 / \mathrm{ft}^{2}$ in elementary school, $\$ 1.38 / \mathrm{ft}^{2}$ in middle school, and $\$ 1.35 / \mathrm{ft}^{2}$ in high school, respectively [9]. Educational buildings which include classrooms, preschool/day-care, elementary/middle/high school, and college/university consume $37 \%$ of total electricity consumption for HVAC systems [8]. Energy usage in schools is not only related to the schools' operational expenditure but is also connected to reducing energy consumption and $\mathrm{CO}_{2}$ emission. School as a public building has a responsibility of energy performance and indoor environmental quality [10]. A recent study has predicted that the total world energy usage will increase by $56 \%$ from 2010 to 2040 [11]. Buildings consume 50 $\%$ of total building energy usage and $20 \%$ of total energy consumption in USA to operate HVAC systems [12]. According to a previous study comparing energy usage of offices in U.S. cities, energy consumption reduced $1.5 \% \sim 29.0 \%$ when the ventilation strategy changed from mechanical to natural ventilation [13]. HVAC systems have become essential for thermal comfort and desired indoor air quality. The increase of building's energy consumption is inevitable. Since different school levels have different human density and occupational time, consequently, different energy consumption [10], schools' requirements need to be considered before determining an energy efficient ventilation strategy which will also ensure health and productivity.

Several studies have investigated the effect of ventilation system using carbon dioxide $\left(\mathrm{CO}_{2}\right)$ or particulate matter as tracers/indicators [14, 15], but few studies have assessed the impact on indoor microbes. Microorganisms in an indoor space reflect the combined

\footnotetext{
* Corresponding author: hoques@cec.sc.edu
} 
effects of the presence of occupants, activities, environmental parameters and specific characteristics of the space. For instance, human-related bacteria such as Staphylococcus sp. and Micrococcus ap. are frequently found in building environment [16]. Different age groups have different microbial flora [17]. Since Lactobacillus sp. is a vaginal microorganism, it has been frequently detected in female related spaces while Corynebacterium $\mathrm{sp}$. has been found in male-related rooms [18]. Meadow and his colleagues confirmed that individuals have their own biological cloud and release their distinctive microbes in the spaces [19]. Human activity changes the indoor microbial communities and concentrations [20].

Although numerous studies have found that the indoor microorganisms differ depending on the indoor conditions, current ventilation standards do not use microbial presence as a way of assessing, 'adequate ventilation' [21]. Indoor microbial communities were highly influenced by the ventilation strategy [22]. In this study, the relationship between indoor microbial characteristics and engineering controls have been investigated.

\section{Materials and methods}

Microorganism and particulate matter were obtained from sampling in classrooms, locker rooms, and libraries in two high schools and an elementary school. The spatial distribution of the microbial quantity and diversity was assessed in relation to the interior orientation of engineering controls (such as vents) and select interior 'décor' such as placement of desks, book shelves, sinks etc. All the schools were always mechanically ventilated and had windows (closed) except for the locker rooms which had no windows. Indoor microorganisms were collected through passive air sampling for 60 minutes using open Petri dishes filled with tryptic soy agar (TSA). The passive air sampling method follows the standard 1/1/1 scheme (1 $\mathrm{hr}$ exposure, $1 \mathrm{~m}$ above the floor, and $1 \mathrm{~m}$ far from the wall) [23]. The locations of the Petri dishes in this study were varied in relation to the HVAC system vents in order to investigate the influence of the ventilation system. Optical Particle Sizer 3330 (TSI Inc., MN, USA) was used to measure particle size distribution. Indoor environmental conditions were monitored using ABM200 (Airflow and Environmental Meter, CPS Products, Inc., FL, USA). Temperature and humidity were recorded typically at $\sim 26{ }^{\circ} \mathrm{C}$ and $\sim 47 \%$, respectively. Samples were collected from October 2017 to February 2018. Occupancy and activity were recorded. The degree of activity was rated in three levels: -1 (no activity, unoccupied), 0 (normal activity: sitting, talking, or walking), and +1 (high activity: running or most people is moving around).

Sampled Petri dishes were incubated at the room temperature for 7 days. The shape, colour, and texture of the colony were evaluated for microbial identification. Colony forming units per $\mathrm{m}^{3}$ of indoor air $\left(\mathrm{CFU} / \mathrm{m}^{3}\right)$ were calculated to quantify the concentration of indoor microbes applying equation (1) [24, 25]:

$$
C F U / m^{3}=\frac{5 \times n \times 10^{4}}{A \times t}
$$

where $n$ is the number of colonies on the Petri dish, $A$ is the surface area of the Petri dish $\left(\mathrm{cm}^{2}\right)$, and $t$ is exposure time (min).

Overall 160 air samples were collected. For the data reliability, duplicate samples were taken at the same sampling location. R 3.5.1 and Minitab (Minitab Inc., PA, USA) were used for statistical analysis. The data significance was evaluated at $p$ level of 0.05 . Canonical correspondence analysis (CCA) was applied to determine the influence of sampling condition and distance from the vent. CCA represented the relationships between biological species and their environment [26]. One-way ANOVA test was applied to evaluate the differences among the samples.

\section{Results and Discussion}

\subsection{Indoor air quality}

Indoor air quality was evaluated with the concentrations and types of detected microorganism, and particulate matter. Overall 160 air samples were collected. Among the samples, six different bacteria and seven different fungi were identified. Detected bacterial species were Bacillus sp., Staphylococcus sp., Curtobacterium sp., Aerococcus sp., Micrococcus sp., and Corynebacterium sp. Detected fungi were Rhodotorula sp., Cochliobolus spp., Pithomyces sp., Alternaria sp., Ascochyta sp., Aspergillus sp., and Penicillium spp. The most abundant microorganisms were Staphylococcus sp., Bacillus sp., and Micrococcus sp. This result is in accordance with other studies in the literature. Staphylococcus sp., Bacillus sp., Corynebacterium sp., and Micrococcus sp. are frequently found in indoors such as residences, hospitals, offices, or schools since they are humanrelated bacteria [20, 27-29]. A study conducted in airconditioned office buildings found Micrococcus sp., Bacillus sp., Staphylococcus sp., Penicillium sp., Aspergillus sp., and Rhodotorula sp. from the air and settled dust samples [28].

Indoor microbial concentration in each school and space is described in Fig. 1(A). Elementary school showed a higher microbial concentration, especially in kindergarten, than high school. The averaged concentrations were $135 \mathrm{CFU} / \mathrm{m}^{3}$ in high school and 293 $\mathrm{CFU} / \mathrm{m}^{3}$ in elementary school, respectively. The ANOVA test confirmed that human activity $(p<0.05)$ had a significant influence on the microbial concentration. No activity was reported in the $5^{\text {th }}$ grade classroom. Fig. 1(A) shows that the number of microbes detected is higher in male's locker room even when both locker rooms had similar activities and occupancy rates. Gender did not significantly impact the number of 
detected microorganisms $\left(\mathrm{CFU} / \mathrm{m}^{3}\right)$ and microbial species $(p>0.05)$. Fungal and bacterial concentration were highly influenced by the types of room $(p<0.05)$. Relatively higher fungal level was measured in library (median: $23 \%$ ) than other rooms (median: $8 \%$ in locker room and $11 \%$ in classroom, respectively).

Fig. 1(B) shows the concentration of particulate matter (PM2.5). In accordance with the indoor microbial concentration, Fig. 1(A), particulate matter was higher in kindergarten.

(A)

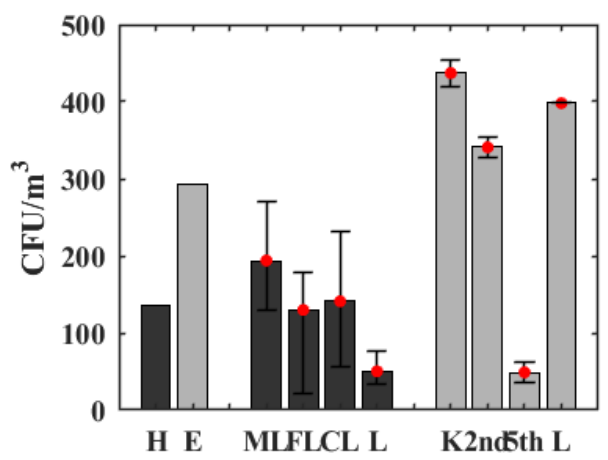

(B)

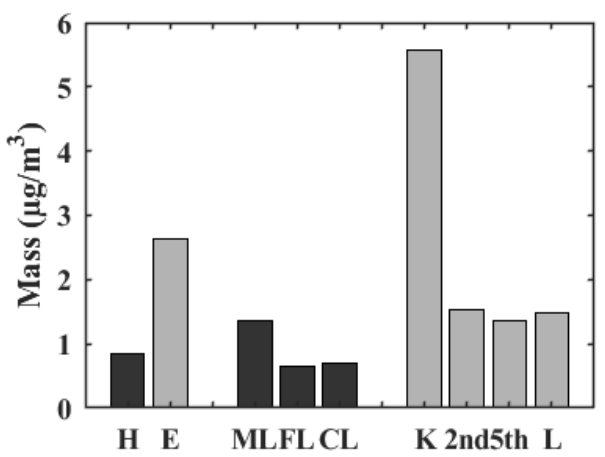

Fig. 1. (A) Microbial concentration $\left(\mathrm{CFU} / \mathrm{m}^{3}\right)$ and (B) $\mathrm{PM} 2.5$ $\left(\mu \mathrm{g} / \mathrm{m}^{3}\right)$ in each sampling location. $\mathrm{H}$ : High school, E: Elementary school, ML : Male's locker room, FL : Female's locker room, CL : Classroom, L : Library, K: Kindergarten, 2 nd $: 2^{\text {nd }}$ grade classroom, and 5 th $: 5$ th grade classroom.

\subsection{Influence of sampling condition}

Canonical correspondence plot (Fig. 2) showed and confirmed the relation between sampling location and microbial community. The types of room are classified into locker room, classroom, and library. Adolescence and children represented two different age groups. The three schools are: two high schools and an elementary school. Gender indicates: female only, male only, and both genders present. CCA results show that gender and types of school had a significant effect $(p<0.05)$. As shown in Fig. 2 the presence of Bacillus sp., Aerococcus sp., Corynebacterium sp., and Penicillium sp. is highly related to gender, while Staphylococcus sp. and Alternaria sp. are related to types of school. Numerous studies have found that Corynebacterium sp. is dominant in male-occupied rooms [17, 18, 30]. Bacillus sp. is often found in indoor air and dust samples [29],
Aerococcus sp. is known as an environmental species [31], and Penicillium sp. is one of the most common indoor fungi [31]. However, previous studies have not investigated the relation between Bacillus sp., Aerococcus sp., and Penicillium sp. and gender.

The presence of Aspergillus sp., Rhodotorula sp., Ascochyta sp., Cochliobolus sp., Micrococcus sp., and Curtobacterium sp. was not associated with the types of room, school, age, and gender. Aspergillus sp. is frequently detected indoors, while Cochliobolus sp. is an outdoor-related fungus [28, 31, 32]. Rhodotorula sp. is abundant in indoor and outdoor air samples [33].

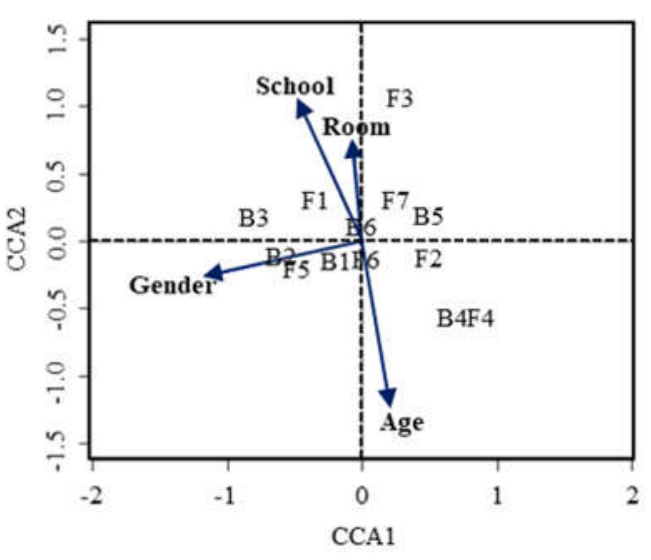

Fig. 2. CCA plot showing overall detected microorganisms among different sampling conditions. B1 : Aerococcus sp., B2 : Bacillus sp., B3 : Corynebacterium sp., B4: Curtobacterium sp., B5: Micrococcus sp., B6: Staphylococcus sp., F1: Alternaria sp., F2 : Ascochyta sp., F3 : Aspergillus sp., F4 : Cochliobolus sp., F5 : Penicillium sp., F6 : Pithomyces sp., and F7 : Rhodotorula sp.

\subsection{Influence of vent location}

The spatial distribution of microbial diversity and quantity was investigated to determine the influence of vent location. Fig. 3 shows the location of sampling sites, vents, doors, and windows. The ratio of detected bacteria and fungi was not significantly influenced by the distance from vents $(p>0.05)$. However, the presence of Aerococcus sp. and Micrococcus sp. were significantly influenced by the vent location $(p<0.05)$. Aerococcus sp. is outdoor-related species and Micrococcus sp. is associated with human presence [31]. Relatively lower number of Aerococcus sp. was detected when the distance between sampling site and vent was less than $2 \mathrm{~m}$. Micrococcus sp. was generally detected when the distance was lower than $3.5 \mathrm{~m}$. Higher number of Micrococcus sp. was observed over $4 \mathrm{~m}$ away from the closest vent. This result demonstrates a possibility of the influence of the zones in the room with different range of velocity magnitudes influencing the presence of microbes. The number of detected bacteria $\left(\mathrm{CFU} / \mathrm{m}^{3}\right)$ was highly impacted by the distance from the closest window $(p<0.05)$. However, each microbial species was 


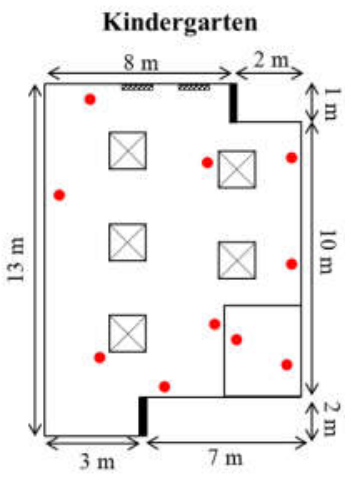

$5^{\text {th }}$ grade classroom

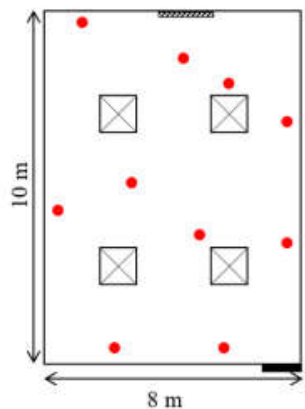

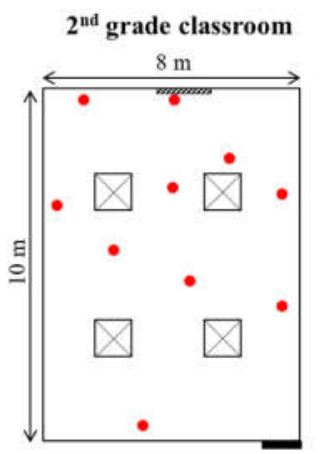

Classroom in high school

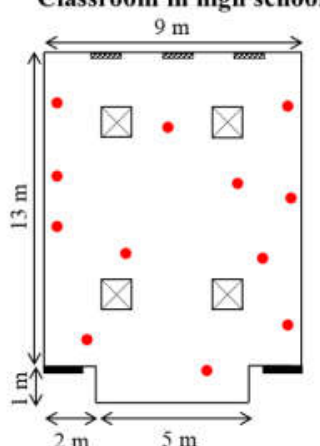

Library in elementary school
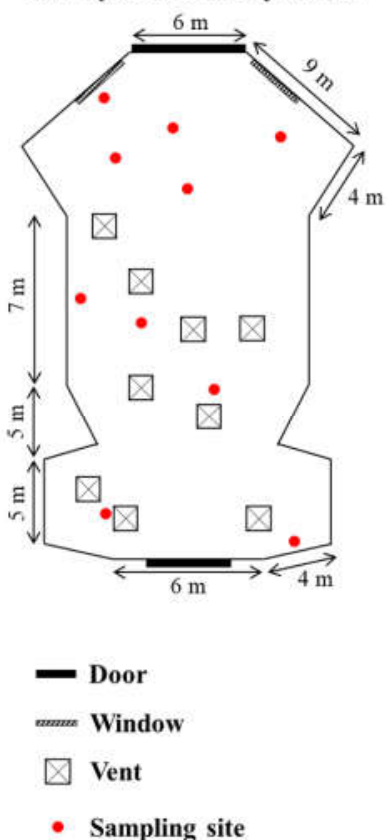

Fig. 3. Schematic diagram of the location of vents, doors, windows, and sampling sites.

not significantly influenced by the window location $(p>0.05)$. The distance between sampling site and the door was not significant among the all microbial species $(p>0.05)$.

\section{Conclusion}

The study investigated the microbial concentration and particulate matter in different sampling conditions. Samples were collected from two high schools and an elementary school. Air sampling from locker rooms, classrooms, and library were investigated to identify the influence of age, gender, space occupancy, and activity. Six different bacteria and seven different fungi were detected. Bacterial species were Bacillus sp., Staphylococcus sp., Curtobacterium sp., Aerococcus sp., Micrococcus sp., and Corynebacterium sp. Fungi were Rhodotorula sp., Cochliobolus spp., Pithomyces sp., Alternaria sp., Ascochyta sp., Aspergillus sp., and Penicillium spp. Higher microbial concentration was observed in kindergarten where the highest activity rate was measured. In agreement with previous studies, male's locker room showed relatively higher concentration of microorganisms and particulate matter $[18,19]$. Our CCA result confirmed that the microbiome at different schools (high school and elementary school) and gender were significantly different. Staphylococcus sp. and Alternaria sp. are highly related to types of school, while the presence of Bacillus sp., Aerococcus sp., Corynebacterium sp., and Penicillium sp. is mainly related to gender. The analysis determined that the ratio of bacteria and fungi was not significantly influenced by the vent location. However, several bacterial species showed differences depending on the distance from the closest vent, Aerococcus sp. and Micrococcus sp. The distance from the door was not significant among all the microbial species. Aerococcus sp. and Micrococcus sp. were detected in spaces with natural and mechanical ventilation system $[34,35]$.

The results of the analysis indicate that while the spaces were continually mechanically ventilated maintaining acceptable humidity and indoor temperature conditions, the effects on indoor microbial diversity and quantity needs further evaluation. Outdoor related microorganisms such as Aerococcus sp. and Bacillus sp. were continuously detected in the mechanically ventilated spaces. There was no impact of window or door locations to the presence or absence of the detected species. Understanding how other ventilation approaches such as natural, hybrid or personalized ventilation systems impact the spatial distribution of the microbiome can lead to more energy efficient designs and healthy indoor conditions. The characteristics of the microbiome can also have an influence, which remains to be investigated.

\footnotetext{
* Corresponding author: hoques@cec.sc.edu
} 


\section{References}

1. W. Deng, Y. Chai, H. Lin, W.W. So, K. Ho, A. Tsui, R. Wong, AtmEn, 128, 268-275 (2016)

2. L. Bouillard, O. Michel, M. Dramaix, M. Devleeschouwer, Ann. Agric. Environ. Med., 12, 187-192 (2005)

3. A. Mendes, S. Bonassi, L. Aguiar, C. Pereira, P. Neves, S. Silva, D. Mendes, L. Guimarães, R. Moroni, J.P. Teixeira, Urban Climate, 14, 486$501(2015)$

4. M. Arif, M. Katafygiotou, A. Mazroei, A. Kaushik, E. Elsarrag, International Journal of Sustainable Built Environment, 5, 1-11 (2016)

5. M. Lee, K. Mui, L. Wong, W. Chan, E. Lee, C. Cheung, Build. Environ., 49, 238-244 (2012)

6. P. Spiru, P.L. Simona, Energy Procedia, 128, 179-186 (2017)

7. G. Cao, H. Awbi, R. Yao, Y. Fan, K. Sirén, R. Kosonen, J.J. Zhang, Build. Environ., 73, 171$186(2014)$

8. EIA, (2012)

9. M. Vadney, B. Fox, M. Mosser, S. Fraser, B. Bernstein, in ACEEE Summer Study on Energy Efficiency in Buildings. 2012: CA, USA. p. 367-379.

10. L.D. Pereira, D. Raimondo, S.P. Corgnati, M.G. Da Silva, Renewable and Sustainable Energy Reviews, 40, 911-922 (2014)

11. A. Allouhi, Y. El Fouih, T. Kousksou, A. Jamil, Y. Zeraouli, Y. Mourad, Journal of Cleaner production, 109, 118-130 (2015)

12. L. Pérez-Lombard, J. Ortiz, C. Pout, Energy and buildings, 40, 394-398 (2008)

13. T. Ben-David, M.S. Waring, Build. Environ., 104, 320-336 (2016)

14. J. Liu, X. Dai, X. Li, S. Jia, J. Pei, Y. Sun, D. Lai, X. Shen, H. Sun, H. Yin, Build. Environ., (2018)

15. H.-J. Oh, I.-S. Nam, H. Yun, J. Kim, J. Yang, J.-R. Sohn, Build. Environ., 82, 203-214 (2014)

16. A. Barberán, R.R. Dunn, B.J. Reich, K. Pacifici, E.B. Laber, H.L. Menninger, J.M. Morton, J.B. Henley, J.W. Leff, S.L. Miller. in Proc. R. Soc. $B$ (2015)

17. S. Ying, D.-N. Zeng, L. Chi, Y. Tan, C. Galzote, C. Cardona, S. Lax, J. Gilbert, Z.-X. Quan, PLoS One, 10, e0141842 (2015)

18. J.C. Luongo, A. Barberán, R. Hacker-Cary, E.E. Morgan, S.L. Miller, N. Fierer, Indoor Air, 27, 338-344 (2017)

19. J.F. Meadow, A.E. Altrichter, A.C. Bateman, J. Stenson, G. Brown, J.L. Green, B.J. Bohannan, PeerJ, 3, e1258 (2015)

20. M. Miletto, S.E. Lindow, Microbiome, 3, 61 (2015)

21. EPA, (2014)

22. J.F. Meadow, A.E. Altrichter, S.W. Kembel, J. Kline, G. Mhuireach, M. Moriyama, D. Northcutt, T.K. O'Connor, A.M. Womack, G.Z. Brown, J.L. Green, B.J. Bohannan, Indoor Air, 24, 41-48 (2014)
23. C. Pasquarella, O. Pitzurra, A. Savino, J. Hosp. Infect., 46, 241-256 (2000)

24. M. Stryjakowska-Sekulska, A. PiotraszewskaPajak, A. Szyszka, M. Nowicki, M. Filipiak, Pol J Environ Stud, 16, 623 (2007)

25. S.F. Hayleeyesus, A.M. Manaye, Asian Pac. J. Trop. Biomed., 4, S312-S317 (2014)

26. C.J. Ter Braak, P.F. Verdonschot, Aquat. Sci., 57, 255-289 (1995)

27. S.C. Verde, S.M. Almeida, J. Matos, D. Guerreiro, M. Meneses, T. Faria, D. Botelho, M. Santos, C. Viegas, Res. Microbiol., 166, 557-563 (2015)

28. M. Gołofit-Szymczak, R.L. Górny, Int. J. Occup. Saf. Ergonomics, 16, 465-476 (2010)

29. J. Karbowska-Berent, R.L. Górny, A.B. Strzelczyk, A. Wlazło, Build. Environ., 46, 1872-1879 (2011)

30. Z. Gao, C.-h. Tseng, Z. Pei, M.J. Blaser, Proceedings of the National Academy of Sciences, 104, 2927-2932 (2007)

31. S. Bonetta, S. Bonetta, S. Mosso, S. Sampò, E. Carraro, Environ. Monit. Assess., 161, 473-483 (2010)

32. K.C. Dannemiller, J.F. Gent, B.P. Leaderer, J. Peccia, J. Allergy Clin. Immunol., 138, 76-83. e71 (2016)

33. R.I. Adams, M. Miletto, J.W. Taylor, T.D. Bruns, The ISME journal, 7, 1262 (2013)

34. S.-K. Shin, J. Kim, S.-m. Ha, H.-S. Oh, J. Chun, J. Sohn, H. Yi, PLoS One, 10, e0126960 (2015)

35. A. Hoisington, J. Maestre, K. Kinney, J.A. Siegel, Indoor Air, 26, 857-868 (2016) 